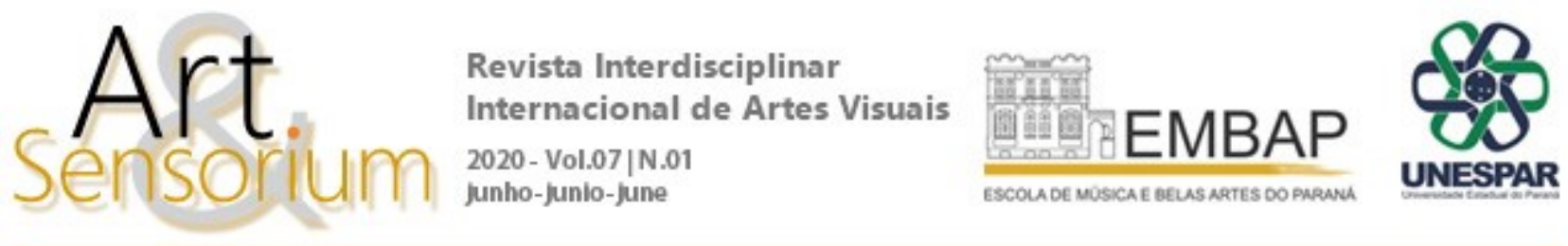

\title{
A ARTE DE PAULO BRUSCKY E O SISTEMA PARA A IRONIA
}

DOI: https://doi.org/10.33871/23580437.2020.7.1.215-233

Deisi Beatriz Barcik ${ }^{1}$

Resumo: Esse artigo, adaptação de um capítulo da dissertação defendida em 2017, aborda proposições do artista Paulo Bruscky realizadas nos anos iniciais da década de 1970. Fazem parte do estudo Arte Cemiterial e os seus desdobramentos e Opinião da Obra sobre o espectador, trabalhos em que o artista recifense parece direcionar sua ironia mais enfaticamente ao sistema de arte, aí incluídos as exposições, as galerias e os museus, os críticos, o júri dos salões, a academia de arte, o público e a ideia de exposição e apreciação estética puramente visual. O artigo é construído sobre proposições artísticas que concedem certo acesso a uma das características que Bruscky deixa transparecer sobre sua produção: usar a criatividade como subversão, assim, tais proposições são analisadas sobre o prisma da ironia e da paródia utilizando, para isso, os conceitos de Linda Hutcheon.

Palavras-chave: Paulo Bruscky; sistema artístico; ironia; paródia.

\section{PAULO BRUSCKY'S ART AND THE SYSTEM FOR IRONY}

Abstract: This article, adapted from a chapter of the dissertation defended in 2017, addresses propositions by artist Paulo Bruscky made in the early 1970s. They are part of the study Arte Cemiterial and its developments and "Opinião da Obra sobre o espectador", both productions in which the artist from Recife seems to direct his irony more emphatically to the artistic system, including exhibitions, galleries and museums, critics, the jury of the halls, the art academy, the public and the idea of exhibition and purely visual aesthetic appreciation. The article is built on artistic propositions that allow some access to one of the characteristics that Bruscky reveals about his production: using creativity as a subversion, thus, such propositions are analyzed under the perspective of irony and parody using, for this, the concepts by Linda Hutcheon.

Keywords: Paulo Bruscky; artistic system; irony; parody.

\section{EL ARTE DE PAULO BRUSCKY Y EL SISTEMA PARA LA IRONÍA}

Resumen: Este artículo, adaptación de un capítulo de la tesis defendida en 2017, aborda propuestas del artista Paulo Bruscky realizadas en los primeros años de la década de 1970, específicamente Arte Cementerial y sus desdoblamientos y Opinião da obra sobre o espectador. En ellas, el artista recifense parece dirigir su ironía más enfáticamente hacia el sistema de arte, incluidas las

\footnotetext{
${ }^{1}$ Doutoranda no Programa de Pós-Graduação em História da Universidade Federal do Paraná, (Curitiba, Brasil) pela linha de pesquisa Arte, Memória e Narrativa, com financiamento da Coordenação de Aperfeiçoamento de Pessoal de Nível Superior (CAPES). Concluiu o Mestrado em História, também pelo Programa de Pós-Graduação em História da Universidade Federal do Paraná, com bolsa CAPES, em 2017. Possui graduação em Artes Visuais pela Faculdade de Artes do Paraná, Universidade Estadual do Paraná (2013). https://orcid.org/0000-0002-4284-7803. e-mail: beatrizbarcik@gmail.com
} 
exposiciones, las galerías y los museos, los críticos, los jurados de los salones, la academia de arte, el público y la idea de exposición y apreciación estética puramente visual. El artículo está construido sobre propuestas artísticas que conceden cierto acceso a una de las características que Bruscky deja traslucir sobre su producción: usar la creatividad como subversión, así, tales proposiciones son analizadas bajo el prisma de la ironía y de la parodia utilizando, para eso, los conceptos de Linda Hutcheon.

Palabras clave: Paulo Bruscky; sistema artístico; ironía, parodia.

Desde o início da década de 1960, no Brasil, algumas formas de representação apareceram mais contextualizadas e comprometidas com a realidade social. Após o golpe militar em 1964, o experimentalismo nas artes se intensifica. A rejeição aos princípios tradicionais que definem o que é uma obra de arte vai ganhando força e o comprometimento com as questões reais da sociedade passa, mais efetivamente, a fazer parte da poética de vários artistas, sobretudo após a promulgação do AI-5, em 1968. Assim, muitos artistas atuantes nas décadas de 1960 e 1970 se ocuparam em propor trabalhos que servissem, de algum modo, como possibilidade de liberdade de expressão e como intervenção na situação repressiva vivida durante a ditadura militar. Muito dessa produção se configurou como alternativa crítica ao sistema da arte, mas, além disso, à esfera política e, de modo geral, ao comportamento social. Vários artistas desenvolveram trabalhos em que os recursos poéticos os afastaram das definições mais restritas do que seria a arte - um quadro, uma escultura - e os aproximaram do que ficou conhecido como "arte conceitual" ou "conceitualismo".

A discussão sobre os termos "arte conceitual" e "conceitualismo" é densa, pois há diversas abordagens sobre eles e suas características, que por vezes se tocam e se confundem. Alguns autores tentam delimitar as denominações, outros preferem reconhecer a dificuldade em situar os limites que os definem. Nesse texto, baseado em estudos sobre a produção conceitual no contexto brasileiro e latino-americano ${ }^{2}$, a opção é utilizar o termo "arte conceitual" que, a partir daqui sem aspas, de modo geral, poderia ser orientado como táticas utilizadas por artistas para veicular suas ideias não apenas através de objetos, mas de ações e proposições de arte. Tais ideias artísticas, em grande parte críticas, podem apresentar como foco de questionamento o próprio objeto e o sistema de legitimação da arte, daí a premissa - de raiz norte americana e europeia - da não preocupação com a produção de um produto final, embora isso não se estabeleça, principalmente no contexto latino-americano, como total negação da materialidade. Além disso, no contexto brasileiro, a arte conceitual abrangeu questões políticas, sociais, culturais e históricas específicas do período. Tais ações, situações ou proposições , através de vários recursos poéticos, se constituíram, de maneira ampla, como formas alternativas e estratégicas para a circulação da ideia artística em textos, performances, happenings, vídeo arte, arte postal, fotografia etc., e, para além da apreciação estética relacionada ao juízo de gosto, contaram com as funções do espectador de modo mais conectado à atividade intelectual e participativa.

\footnotetext{
${ }^{2}$ Em Poéticas do processo, Cristina Freire (1999, p. 15-16) afirma que se vale da "denominação arte Conceitual num sentido estendido (aqui equivalente à arte de endereçamento conceitual e conceitualismo)". Pois mais relevante são "as estratégias utilizadas na elaboração das obras (preponderância da ideia), algumas características frequentes nas proposições (especialmente a transitoriedade dos meios e a precariedade dos materiais utilizados), a atitude crítica frente às instituições artísticas (...), assim como as particularidades nas formas de circulação e recepção (...)". Em Arte Conceitual, Freire (2006, p. 7-10), considera a discussão sobre os termos ainda difusa e inconclusa, mas opta por "arte conceitual", considerando a efemeridade das proposições, a possibilidade reprodutiva, a contextualização, as poéticas de apropriação e a determinante função intelectual na recepção dos trabalhos como princípios norteadores. Em Conceitualismos do Sul, Freire (in FREIRE; LONGONI, 2009, p. 165-166) comenta que o uso do termo "não se trata (...) de importar um rótulo (...), mas antes de encontrar uma plataforma comum de intercâmbio para entender (...) a produção conceitual nos países periféricos. Dária Jaremtchuk, (2007, p.22) observando os princípios de Peter Osborne que considera o termo "conceitualismo" demasiado amplo, também opta pelo termo "arte conceitual", indicando a "rejeição à definição tradicional de abra de arte" como um aspecto comum, inclusive para o contexto latino-americano.
}

R. Inter. Interdisc. Art\&Sensorium, Curitiba, v.7, n.1, p. 215 - 233 Jan.- Jun. 2020 
Entre os recursos que compõem ou colaboraram com as estratégias de produção ou circulação de arte no período, supõe-se, está o uso da ironia, que se configurou como um elemento apropriado para que artistas pudessem produzir com certa liberdade e, diversas vezes, se posicionar e criticar a instituição arte, a sociedade e a política do governo militar. A ironia, assim como a arte conceitual, não é um termo facilmente definível. Ela é instável e teve abordagens diversas e em variadas áreas do conhecimento. Aqui, empregando os estudos de Linda Hutcheon (2000), a ironia é pensada como sendo polissêmica e utilizada, então, também como conceito operatório para a análise das proposições, considerando o contexto discursivo, de forma interativa, transideológica e politizada.

Como atividade discursiva, a ironia, que é social, mas não se ocupa em trazer verdades ou certezas, age mais no sentido de deslocar convicções. Por ser polissêmica, acontece na interação entre o que está e o que não está declarado. A natureza transideológica da ironia, que é também responsável pela falta de garantias quanto às interpretações, somada com sua aresta crítica, acredita-se, fazem dela uma forma possível de oposição. "Operando quase que como uma forma de guerrilha, a ironia é vista como se trabalhasse para mudar a maneira de interpretar das pessoas." (HUTCHEON, 2000, p. 56). Ou seja, a ironia - que pode embaraçar, humilhar, ridicularizar, embora não seja sinônimo de humor - seria um modo apropriado para que aqueles que se opões às normas dominantes ou aos sistemas sejam ouvidos, solapando e desiquilibrando esses sistemas, mas mantendo distância crítica

Assim, falando através do discurso que buscava contestar, em 1970, o jovem artista recifense Paulo Bruscky, que iniciara a divulgação de seu trabalho com desenho em 1966, através do jornal Diário de Pernambuco, e que em 1969 já havia sentido a censura, deslocava representações e suas exposições eram noticiadas no jornal. 18 de julho de 1970, Valdi Coutinho (1970, p.5), crítico cultural do Recife, anunciava, no Diário de Pernambuco, a exposição que seria aberta na galeria da Empresa de Turismo de Pernambuco, Empetur" ${ }^{3}$ No dia 6 de agosto, uma nota na primeira página: "Cemitério é tema de pintura (...). Um caixão fará parte da mostra e dentro o público poderá observar uma das pinturas de Paulo Bruscky, que gosta de cemitérios e por isso transferiu seu "hobby" para sua arte (...)" (Cemitério..., 1970, p.1). Na página 3, continuava:

(...) quem entrar na galeria da EMPETUR, não precisa se assustar com o caixão mortuário (...). Será um toque de originalidade na exposição do desenhista Paulo Bruscky. (...) abordando temas populares e explorando uma nova característica no desenho, que ele chama de arte cemiterial. Desenho no Caixão. (...) que poderá ser velada pelo público, sem que seja preciso levar velas nem lenço para enxugar as lágrimas. Não será, também, proibido entrar de vermelho (Recifense..., 1970, p.3)

Se, como aqui se pensa, a partir de 1970, um dos recursos poéticos usados por Paulo Bruscky para se posicionar em relação ao sistema artístico, à política da ditadura militar e ao comportamento social foi a ironia, vê-se que a divulgação de sua exposição também trazia um expediente irônico. Apesar do tom fúnebre emprestado à exposição, a matéria apresentava o ataúde como um "toque de originalidade", dentro do qual haveria um desenho que poderia ser velado ao invés de contemplado. Mas para o "velório" não seria necessário "lenço para enxugar as lágrimas", tampouco tristezas.

A matéria informava que haveria música, veiculava comentários sobre duas das obras que seriam expostas e uma declaração de Bruscky que dizia: "Tudo isso nasceu porque gosto muito de cemitério. Sou atraído pelo silêncio dos túmulos e pelo mistério dos defuntos solenes nos seus caixões"

\footnotetext{
${ }^{3}$ A Empetur foi fundada em 03 de novembro de 1967, durante a gestão do Governador Nilo Coelho (ARENA), vinculada à Secretaria de Turismo, Esporte e Lazer de Pernambuco (SETUREL). Segundo consta, foi o primeiro organismo estadual de turismo do Brasil. Criada para incentivar o turismo e o desenvolvimento econômico e cultural de Pernambuco, estava emparelhada com a Política Nacional de Turismo, como escreveu o jornalista Esdras Bispo, diretor do Departamento de Turismo de Recife: "Nada mais está se fazendo do que colocar em harmonia o turismo municipal, com a política do Governo Federal já seguida pelo próprio governador Nilo Coelho" Fonte: Turismo municipal segue a política da Embratur. Diário de Pernambuco. Recife, 22 out. 1967. p.12.
} 
(Recifense..., 1970, p.3). Ora, o artista se dizia atraído pela solenidade e mistério dos finados, mas parece que no sentido de contrariar o silêncio imperioso da morte (e sobre a morte, principalmente considerando o contexto de exacerbação da violência após o AI-5) e a austeridade do defunto que, neste caso, era um trabalho de arte. Uma das obras destacadas pelo jornal foi Vende-se ou Aluga-se, descrita como um desenho de Cristo Crucificado todo carimbado pelos dizeres de vende-se ou alugase. Bruscky comentou o trabalho dizendo que era uma forma de definição para "essa gente que anda por aí, ganhando dinheiro às custas da religião". A matéria também dizia que havia outros temas além do religioso e cemiterial: "aspectos afro-brasileiros, políticos e fantásticos" (Recifense..., 1970, p.3).

No dia 7 de agosto outras duas publicações no mesmo jornal enaltecendo os talentos de Bruscky “(...) primeira individual de uma das mais positivas esperanças das artes pernambucanas (...)" (Paulo..., 1970, p.11) e reafirmando o convite para a abertura daquela noite. Em outubro, o Diário de Pernambuco informava "Pintores promovem o sepultamento da arte em B. Viagem", outra exposição de Bruscky, mas dessa vez em parceria com Daniel Santiago ${ }^{4}$. Tratava-se de Exponáutica e Expogente (1970), a primeira exposição da dupla Bruscky \& Santiago:

Os pintores Paulo Bruscky e Daniel Santiago realizarão, hoje, (...), duas mostras - a Exponáutica e a Expogente - quando será promovido o sepultamento da arte nas areias da praia. "Sua participação é importantíssima porque você será considerado objeto da exposição", (...) Paulo Bruscky e Daniel Santiago lhe darão oportunidades de, (...) ordenar tudo dentro do seu próprio desejo. (...) se você não gostar de um defunto a arte que estará exposto na praia, você o enterra; se não gostar da composição de um quadro cinético, modificará as cores ao seu gosto ou, se não gostar, pode quebrá-lo e atirá-lo no lixo. (...) "queremos que o povo fique totalmente liberto de qualquer inibição numa exposição de arte”. (...) os convites são igualmente estranhos: são saquinhos de refrescos. Pretendem ser práticos e ao mesmo tempo mostrarem suas qualidades de homens integrados na sociedade de consumo: sua participação começa quando devora o convite. (Pintores..., 1970, p.3)

Em Exponáutica e Expogente, com poética conceitual e expediente irônico, Bruscky e Santiago negavam o valor do objeto arte em vários sentidos. Os artistas ironizavam a arte como mercadoria ao sugerirem que a participação do público começava quando consumisse os convites que, como partes do trabalho, colocados como mercadorias, deveriam ser consumidos, mas, como eram saquinhos de refresco, o consumo, no sentido de ingestão, trazia como consequência a extinção do conteúdo, sobrando apenas o vazio da embalagem. Considerando a arte morta, a promoção do enterro dela nas areias da praia reafirmava a crítica ao objeto ao mesmo tempo em que retiravam a pompa do formato tradicional da exposição: promovendo a ação à beira-mar, convidando o público a participar efetivamente da mostra e, mais do que isso, colocando o espectador na situação de objeto de arte. A intervenção reafirmava a exclusão do luxo e da formalidade dos formatos tradicionais e dava a oportunidade para que o público opinasse e agisse de acordo com seu julgamento, retirando a ideia de arte solene que deveria ser zelada, pois o participante poderia enterrar, quebrar, jogar no lixo o que não gostasse, desde que se sentisse livre e desinibido.

A contar de sua primeira individual, ou seguindo em conjunto com Daniel Santiago, Bruscky dava ares de ironia através de exposições e propostas de intervenção urbana pouco ou nada convencionais, e o Diário de Pernambuco figuravam como importante estratégia para a visibilidade de seu trabalho.

4 Daniel Santiago, pernambucano, iniciou suas atividades artísticas no final da década de 1960. Com projetos questionadores em linguagem experimental, formulou críticas ao contexto político e social daquele momento. Em 1970 conheceu Bruscky com quem formou a dupla "Bruscky \& Santiago", que perdurou de 1970 até 1991, salvo um breve afastamento entre 1981-1982. Apesar de sua longa caminhada artística, apenas em 2012 Santiago teve sua primeira individual, no Museu de Arte Moderna Aluísio Magalhães, em Recife. Sobre a produção de Santiago ver: SILVA, I.M. da. Pernambuco à sombra do golpe: a arte de resistência de Daniel Santiago. Dissertação (Mestrado) - Centro de Artes e Comunicação. Programa de Pós-Graduação em Artes Visuais, Universidade Federal de Pernambuco, Recife, 2014.

R. Inter. Interdisc. Art\&Sensorium, Curitiba, v.7, n.1, p. 215 - 233 Jan.- Jun. 2020 
Ganhador do prêmio do Salão do Museu do Estado de Pernambuco, em 1969, com a obra $O$ Guerrilheiro $^{5}$, Bruscky conquistara confiança e certo reconhecimento. A crítica recifense, principalmente na figura de Valdi Coutinho, o elogiava. Seu nome exaltado constantemente nas páginas do Diário de Pernambuco e a anunciada individual na galeria da Empetur são indicativos de certa consagração artística.

Em 7 de outubro de 1971, seguindo a mesma temática da mostra individual e da Exponáutica e Expogente, Bruscky teve nova mostra na Empetur. No Diário de Pernambuco Valdi Coutinho (1971, p.6) escreveu: "Está chegando o dia da exposição de Paulo Bruscky, que será inaugurada, solenemente, amanhã, na Galeria de Arte da Empetur". No Caderno Feminino, do mesmo impresso, o colunista João Alberto trazia o convite para a exposição, transcrito abaixo:

A família Bruscky convida para a exposição do seu querido filho, primo, neto, irmão e amigo, Paulo Bruscky, a realizar-se no dia 8 de outubro de 1971 na Galeria da Empetur, Avenida Conde da Boa Vista, 785 às 21 horas. Agradece antecipadamente a todos que comparecerem a esse ato de fé e de caridade cristã ${ }^{6}$.

Exaltando os trabalhos do artista como pintor, o colunista colocava a morte como uma temática séria de Bruscky. A ironia pode ser inferida considerando a relação com as propostas anteriores do artista, como a primeira individual (1970) ou o enterro da arte nas areias da praia em Exponáutica e Expogente (1970). A imagem do convite, o desenho do caixão e o texto, tudo colabora para que a proposta não seja vista com o tom sério que João Alberto parecia evocar. A morte não era apenas tema para a pintura de Bruscky, era, ao que parece, subterfúgio para criticar a arte tradicional que, ironicamente, tem sua representação na pintura, além disso, parece que Bruscky chamava a atenção para o aspecto fúnebre presente na política ditatorial. $\mathrm{O}$ texto ainda brinca com a ideia de bondade ligada à moral da caridade e da fé cristã, pois, antecipadamente, o artista agradece o ato de fé e de caridade que seria a participação do público em sua mostra. Se não houvesse nenhuma outra informação, o título poderia levar a crer que se tratava de uma exposição de objetos de arte próprios ou comuns em cemitérios, como esculturas de anjos, santos e crucifixos. Mas não era de esculturas que Bruscky falava, ou seja, o título não quer dizer o que seria possível supor pela literalidade.

\footnotetext{
${ }^{5}$ O Guerrilheiro ficou em $1^{\circ}$ lugar na categoria desenho e o prêmio considerava a aquisição da obra pelo Museu que, no entanto, não ficou com o trabalho, pois ele foi censurado pelo regime militar, fato que obrigou o Museu a fazer uma substituição do desenho premiado por outro de autoria de Bruscky (FREIRE, 2006, p. 187).

${ }^{6}$ Ao lado da imagem do convite, no jornal, João Alberto comentava: "Exposição de Paulo Bruscky: Esta noite, na Galeria da Empetur, vamos ter nova individual do pintor Paulo Bruscky. Trata-se de um dos mais positivos valores da nossa nova geração de artistas. A morte é uma constante nos seus quadros e ele leva tão a sério a coisa que mandou fazer os convites em forma de caixão de defunto, fato inédito e interessante que resolvi reproduzi-lo para vocês". (ALBERTO, J. Exposição de Paulo Bruscky. Diário de Pernambuco, Recife, 8 out. 1971, p. 3.)
} 


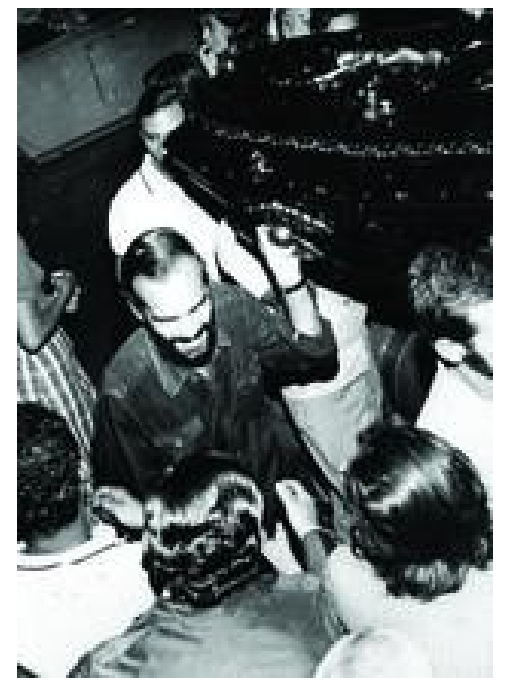

Figura 1 - Arte Cemiterial, Paulo Bruscky, 1971.

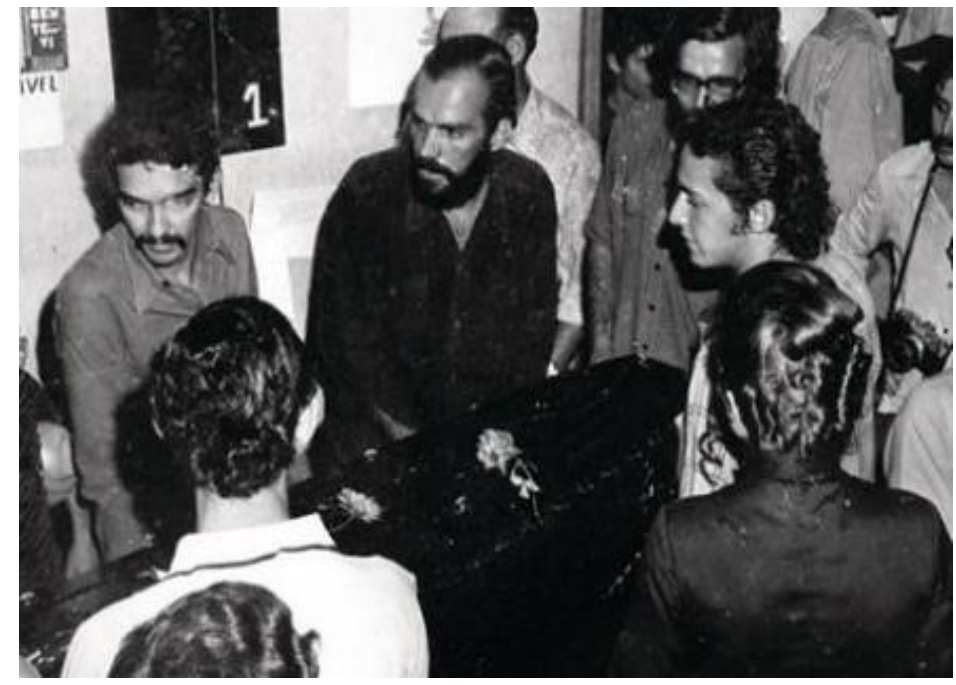

Figura 2 - Arte Cemiterial, Paulo Bruscky, 1971

A abertura da exposição aconteceu no dia 8 de outubro, Bruscky chegou à galeria em um carro funerário. Depois, cercado pelo público e com a ajuda de algumas pessoas, o artista retirou o caixão do carro funerário e com ele acima dos ombros (Figura 1), seguiu sorrindo para entrar na galeria. Já dentro da galeria, o artista aparece agora com um semblante mais sério (Figura 2), mas ainda com a ajuda de algumas pessoas, continua a segurar o caixão sob os olhares dos convidados. Também fizeram parte da mostra o texto Opinião da Obra sobre o espectador, que será analisado adiante.

Uma matéria do Diário de Pernambuco do dia 17 de outubro traz detalhes do acontecimento: "Exposição falava de morte [sic] mas todos estavam pensando na vida", já indica certa rejeição à exposição, o que fica mais claro lendo o conteúdo da matéria:

Vinte e uma horas. Sexta-feira. Início de exposição na Empetur. E o autor da mostra, Paulo Bruscky, de cabelo comprido, barba grande e bigode, chega sorrindo, num carro mortuário, trazendo um ataúde. É evidente que houve risos e gritinhos sincopados. Enquanto o jovem desenhista entrava com o caixão mortuário, era servido um coquetel, à base de batida "sangue de vampiro". Numa mesa, uns pires cheios de capim. E um cartaz dizia o seguinte: sirvam-se. E um dos presentes, escreveu no cartaz: "Todos nós já jantamos. Mas sobrou o suficiente para você, meu caro pintor". Muita gente. Quase todos jovens. Olharam a exposição, comentaram os dotes artísticos do desenhista Paulo Bruscky, mas ficaram só nisso. De todos os trabalhos apresentados, segundo um poeta de vanguarda, o melhor, o mais trabalhado, era um sapato velho, com muita bugiganga dentro. No final da noite, todos beberam o "sangue de vampiro", olharam, citaram pintores, poetas e filósofos. Nenhum quadro vendido. O caixão de defunto que estava lá, num canto, sendo muito admirado pelos olhares curiosos, foi retirado. E os que vieram só para olhar, também foram saindo de mansinho. Ficou só o desenhista-pintor. Já fora do local da exposição, ele comentava agitado: Retiro a mostra segunda-feira. O que foi feito, para felicidade de todos que desejam pensar mais na vida do que na morte (Exposição..., 1971, p.15).

Com a matéria não assinada, era pontuado o descontentamento do público, de autoridades e do jornal. Obviamente, era uma crítica negativa, portanto, parece que o tiro de Bruscky pode ter saído pela culatra. O capim, oferecido como coquetel de abertura, provocava o público, mas a oferta não passou 
despercebida, talvez como o artista esperasse, já que sua ironia crítica também parece direcionada ao comportamento social. A iguaria foi recusada e devolvida ao artista através da frase: "Todos nós já jantamos. Mas sobrou o suficiente para você, meu caro pintor" (Exposição..., 1971, p. 15), escrita no próprio cartaz junto aos pratos de capim em que Bruscky havia escrito "sirvam-se".

No texto, ainda aparecia o comentário de que ninguém havia comprado nenhuma obra e que um poeta de vanguarda havia afirmado que o melhor trabalho era "um sapato velho, com muita buginganga [sic] dentro". Crítica que toma maiores proporções pensando o contexto do jornal, pois para os leitores que não haviam participado da exposição e não sabiam do que se tratava, a impressão, partindo da informação de que um "sapato velho" era a melhor obra, poderia ser bastante negativa. A publicação também colabora para a ideia de rejeição do artista ao afirmar que ele havia ficado só e que a única coisa efetivamente consumida foi a bebida oferecida que recebia o nome de "sangue de vampiro".

Essa não foi a única matéria que apareceu no Diário de Pernambuco naquela semana a respeito da comentada exposição de Bruscky. No domingo, 10 de agosto, o título anunciava: "Empetur retira caixão de defunto de mostra de arte". Essa, também não assinada, informava que o ataúde, peça que fazia parte da exposição de Bruscky, havia sido removido da galeria a mando do diretor da instituição, Sr. Audo Brandley. O motivo da retirada era que o diretor constatara que o caixão era um "acinte aos princípios morais e religiosos" (Empetur..., 1971, p. 27).

Talvez o Sr. Brandley não estivesse enganado, pois desde o convite Bruscky já dava ares de "acinte" aos princípios religiosos, mas talvez o artista ainda não tivesse passado dos limites da tolerância dos personagens cristãos da sociedade recifense ao ponto de sofrer rejeição. Sr. Brandley afirmava: "exposição de arte não é teatro, nem tampouco ocasião para ofender os princípios cristãos da comunidade" (Empetur..., 1971, p. 27). Essa relação com uma encenação, talvez tenha ocorrido porque a exposição não aconteceu de forma tradicional, mas mais aos moldes da arte conceitual. Essa "atuação" de Bruscky poderia então ser entendida como uma performance, mas, por alguns detalhes, talvez se aproxime mais de um happening.

De modo resumido, em happenings música e elementos da dança ou do teatro podem ser utilizados, há hibridações entre as linguagens, mas não se trata de uma encenação; apesar de haver um plano artístico, os roteiros fixos são dispensados e as ações acontecem de acordo com as circunstâncias; conta com reações espontâneas, como improvisações e interações entre artista e público. Já em performances, que também podem conter elementos de outras linguagens artísticas, há um roteiro pré-fixado, o que delimitaria, em teoria, um pouco a ação - do artista e do público (COHEN, 2002). Aliás, o roteiro presente em performances permitiria aos artistas refazer o trabalho, ao contrário de um happening que não poderia ser reproduzido, pois o tempo e as circunstâncias não se repetem. Assim, a ação de Bruscky poderia ser entendida como um happening.

Outro comentário no Diário de Pernambuco dizia que a mostra era uma "apelação" para que o artista ganhasse a atenção do público e informava que Bruscky já havia sido censurado pelos seus colegas da Universidade Católica de Pernambuco dias antes, quando havia afixado nas paredes da instituição cartazes que atentavam contra a moral cristã. Se, por um lado, a matéria no jornal era no sentido de reprimir e promover uma censura moral, comportamental ou religiosa ao artista, inclusive veiculando que seus próprios colegas o censuravam, por outro - alegando que era uma apelação para ganhar atenção do público - a exposição funcionou! A própria matéria que tratava de desabonar o artista, tendo em vista a abrangência de um dos grandes impressos do nordeste - o Diário de Pernambuco poderia colaborar para que ele se tornasse mais conhecido e mais comentado, ainda que os comentários pudessem não ser para enaltecer o artista ou o seu trabalho.

Diante da situação, principalmente em relação à ordem vinda do Sr. Brandley, diretor da Empetur, para que o ataúde fosse retirado, Bruscky se posicionou declarando que retiraria toda a exposição, pois sem o caixão a mostra estaria incompleta. A afirmação do artista sobre a incompletude da exposição sem o ataúde, parece aumentar a importância do caixão, que, nesse caso, poderia ser visto 
como um ready-made, uma apropriação de um objeto do cotidiano transferido para a esfera da arte. Desvinculado da criação artística manual, o caixão expunha um procedimento do artista para que, através de sua escolha, suas ideias, com alto teor de ironia, fossem apresentadas ao público. Considerando o caixão como um ready-made, o "acinte" do artista expressaria seu contorno dadaísta, e a provocação ao sistema artístico seria ainda mais aparente. Vale salientar que a postura artística de Bruscky não é vista aqui como centrada na crítica institucional, mas, como comentou Lidice Matos (2007, p. 119), considera que uma parte de sua produção funciona como crítica, nesse sentido, nas palavras de Matos, "pode ser compreendida como uma forma singular de crítica institucional", fato que não fecharia as proposições do artista em unidades estanques, porque aqui mesmo, ao evocar a morte em um evento cultural, fica também aparente a dimensão política e social da obra de Bruscky.

Embora ter uma exposição encerrada antes da data prevista possa ser muito negativo, isso não foi motivo de estagnação, pois todo o caso e a repercussão parecem ter rendido novas ideias ao artista. A proposta inicial de Bruscky parece que foi então desdobrada e reordenada. Se sua exposição contou com um cortejo fúnebre, pode-se dizer que sua curta duração tenha funcionado como um velório, pois tão logo a exposição ter sido iniciada foi censurada e encerrada. Mas, ao que parece, como que tendo uma carta na manga e com a poética reforçada pela própria situação na galeria e nos jornais, Bruscky demonstrou sua habilidade para lidar com a crítica, com a rejeição e com a censura e produzir arestas irônicas. Oito dias após a Arte Cemiterial ter sido censurada, o artista propôs o "enterro" da exposição. Bem, já que haviam matado sua mostra na galeria, bastava agora enterrá-la.

\section{O enterro da exposição: desdobramentos irônicos?}
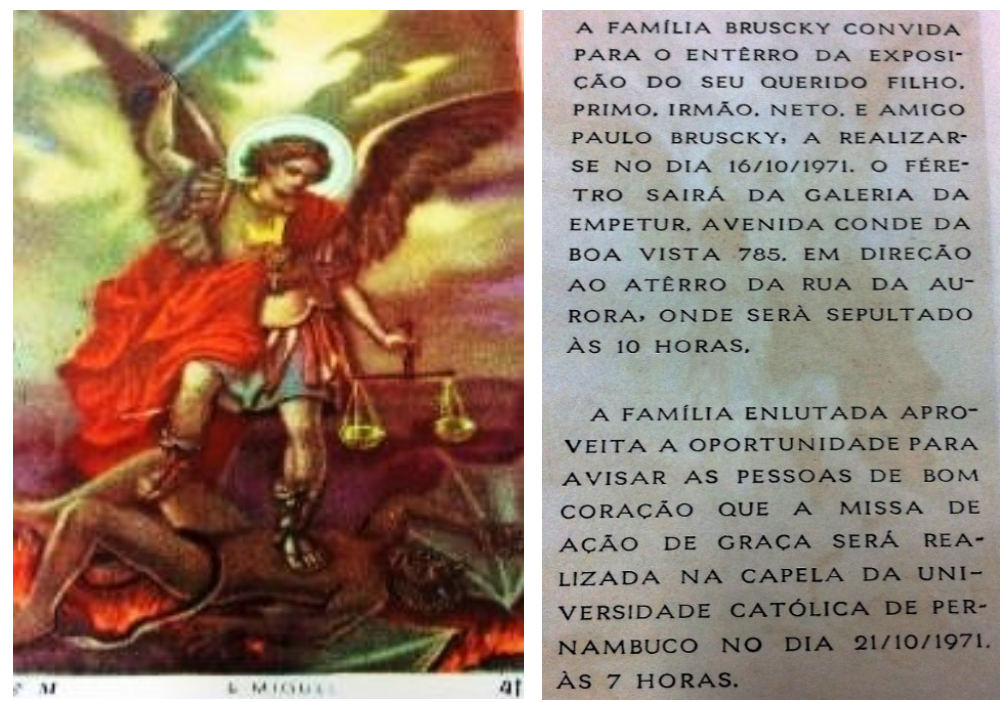

Figura 3 - Arte Cemiterial - Convite Santinho. Paulo Bruscky, 1971

Com convites feitos em santinhos de orações (Figura 3) o artista propôs o enterro da exposição. O cortejo partiria da galeria de arte da Empetur, seguindo pelas ruas da cidade, tendo como fim não um cemitério, o que seria mais apropriado para um enterro, mas a Rua da Aurora, na cidade de Recife. Em entrevista para o Programa Nomes do Nordeste, em 2007, Bruscky comentou:

Cemiterial foi [sic] várias intervenções e essa exposição na Empetur ela foi fechada, né, na noite da abertura e no dia seguinte eu fiz o enterro da censura com o caixão menor, convidei vários amigos e a gente saiu de fronte da galeria da Empetur na época e enterrou esse caixão nas margens do Rio Capibaribe que naquela época você tinha acesso direto ali, perto da... um pouco antes da assembleia (BRUSCKY, 2007). 
Santinho ou pagela são folhetos em pequenos formatos (aproximadamente $10 \mathrm{~cm} \times 5 \mathrm{~cm}$ ) com ambas os lados preenchidos. É comum encontrar a reprodução de imagens estereotipadas de santos católicos em uma das faces e na outra algumas informações sobre o santo representado, orações e orientações para quando e como o santo deve ser evocado. A circulação de santinhos está muito atrelada à prática de ex-voto, ou seja, muitas vezes a circulação dessas imagens acontece com a finalidade de um devoto pagar uma promessa feita ao seu santo de devoção (MENEZES, 2011).

Ainda relacionada ao catolicismo, os santinhos possuem pelo menos outra função, são usados como uma espécie de suvenir quando, por exemplo, os presentes em uma missa de tempo de falecimento recebem dos familiares do morto um santinho de recordação. Nessas ocasiões, é comum que uma das faces traga a imagem de um santo ou do falecido e a outra é preenchida com orações, informações sobre as datas de nascimento e morte além de mensagens saudosas e reconfortantes.

Apesar de haver grande semelhança entre o santinho de Arte Cemiterial e os de uso comum em práticas católicas, esse não é, em teoria, apenas um suvenir ou a divulgação do poder de algum santo, ele é um convite, no qual vemos, em uma das faces, no caso aqui estudado, a imagem de São Miguel Arcanjo $^{7}$. Esse santo, na Bíblia, comanda os exércitos de Deus contra satanás em uma batalha no céu ${ }^{8}$. O santinho é uma ilustração que representa a batalha onde São Miguel vence e lança à terra o Dragão, símbolo do mal, o demônio. Curiosamente, na outra face, o que Bruscky propõe é lançar à terra a obra de arte, enterrá-la. Como se tivesse vencido uma batalha contra a censura e contra as pessoas que se opuseram à sua mostra, com artimanha, o artista se vale do tema e utiliza a pagela para veicular um texto onde aparecem sobreposições de sentidos que se ocultam e se esclarecem simultaneamente: um misto de convite, pesar e ação de graças: ditos, não ditos e entre ditos próprios da ironia.

Se o primeiro convite, com desenho em forma de caixão veiculado no jornal, chamava para a exposição, o texto do segundo, agora em pagela, inicia dizendo o seguinte: "A família Bruscky convida para o enterro da exposição do seu querido filho. Primo. Irmão. Neto. E amigo Paulo Bruscky, a realizar-se no dia 16/10/1971". Nessa passagem acontece uma suspensão de sentido, um convite não para uma exposição, tampouco para o enterro de uma pessoa, mas para o enterro de uma exposição. Embora haja um desencontro entre a data veiculada no santinho, 16 de outubro de 1971, e a informada pelo artista em entrevista para o Programa Nomes do Nordeste - "ela foi fechada, né, na noite da abertura e no dia seguinte eu fiz o enterro da censura com o caixão menor" (BRUSCKY, 2007) - o que corresponderia ao dia 09 de outubro de 1971, o convite trata, ao que parece, do enterro da exposição que havia sido inaugurada na galeria da Empetur, no dia 08 de outubro de 1971, e que havia sido "morta", na mesma noite, por conta da censura.

Além do enterro da censura, declarada pelo artista, o convite também remete ao enterro de uma forma de exposição de arte e, nesse sentido, haveria na proposta uma crítica mais direta estendida à galeria de arte, ainda que o santinho tenha sido produzido após o enterro. Se o enterro realmente aconteceu nas margens do Capibaribe em data anterior à data veiculado na pagela, o santinho seria outro desdobramento da ação do artista. Mesmo assim, isso não retira da fonte a sua função de índice da intervenção ausente, pois remeteria à mesma situação.

A frase seguinte presente na pagela diz: "O féretro sairá da Galeria da Empetur. Avenida Conde da Boa Vista 785. Em direção ao Aterro da Rua da Aurora, onde será sepultado às 10 horas". A palavra "féretro", caixão presente na mostra aberta oito dias antes, formaliza com maior vigor a metáfora da morte e do enterro. O caixão, ainda que não tenha sido o mesmo que estava presente na Empetur,

\footnotetext{
${ }^{7}$ A pagela reproduzida aqui é do acervo de pesquisa do Museu de Arte Contemporânea do Paraná, mas há outro modelo com a imagem de Cristo nas Oliveiras no livro Paulo Bruscky - Arte, Arquivo e Utopia, de Cristina Freire (2006, p. 93).

${ }^{8}$ Houve uma batalha no céu. Miguel e seus anjos tiveram de combater o Dragão. O Dragão e seus anjos travaram combate, mas não prevaleceram. E já não houve lugar no céu para eles. Foi então precipitado o grande Dragão, a primitiva Serpente, chamado Demônio e Satanás, o sedutor do mundo inteiro. Foi precipitado na terra, e com ele os seus anjos (Apocalipse, 12:7-9).
} 
conforme declarou o artista (BRUSCKY, 2007), recebe um corpus artístico mais robusto. Esse corpo/corpus sairia da Galeria de arte da Empetur em direção ao Aterro da Rua da Aurora.

A Rua da Aurora, em Recife (PE), foi construída no aterro feito sobre uma área de mangue na margem esquerda do Rio Capibaribe. O nome da rua é porque todas as edificações, de frente para o Rio, têm as faces voltadas para o leste. Famosa em poemas de Manoel Bandeira, como em Cotovia: "Voei ao Recife, no Cais / Pousei na Rua da Aurora. / Aurora da minha vida / Que os anos não trazem mais!", a rua é um cartão postal da cidade. Mas, antes, é e foi o endereço de algumas repartições públicas: hoje é local da Assembleia Legislativa do Estado de Pernambuco; no período da ditadura militar foi a Delegacia de Ordem Política e Social, DOPS, que lá funcionou até $1983^{9}$ - daí um elemento que também confirmaria a aresta política da tática irônica da proposta do artista.

Por isso, talvez aqui, aconteça outra sobreposição. Não há só incongruência nas informações, há um espaço entre o que está expresso no convite-santinho e o que pode ser entendido ou se procura entender. E é no entre que a ironia costuma acontecer. Aurora é o momento que anuncia, no horizonte, o nascer do sol, são as primeiras luzes de um novo dia. O corpo que será enterrado, fechado em seu ataúde, sairá da Galeria de arte e seguirá pelas ruas da cidade do Recife e finalmente, anuncia o convite, será sepultado na (rua da) Aurora. Um sepultamento marca o fim de alguém, no caso, de algo, marca o fim da exposição; já aurora, em sentido figurado, indica surgimento, anuncia o raiar de um novo dia. No espaço entre uma informação (de fim) e outra (de início) parece estar a ironia do artista que joga com as palavras e seus significados e com a mídia em que a mensagem é veiculada.

As especulações aqui não são avaliativas, mas interpretativas e construídas a partir de inferências. Nesse sentido, os parágrafos anteriores não querem dizer que a interpretação é a de que o que Bruscky propôs faça referência ao fim de um tipo de arte e início de outra. Se o título e a proposta apresentam a ideia de morte da arte, genericamente, tal semelhança que há entre a ideia de morte como fim, poderia nos remeter ao "fim da arte", conceito anunciado por Hegel no início do século XIX, e abordado por Arthur Danto no século XX, além disso, o local proposto por Bruscky para o enterro da arte - a Rua da Aurora - bem poderia colaborar, de certo modo, para fazer uma ligação entre a proposta do artista e os pensamentos de Hegel ou Danto, no sentido de que proposta e título tanto marcava um fim como anunciava o início de algo novo, mas isso é apenas uma inferência, e não quer dizer que Bruscky teve a intenção de tratar da morte da arte nos termos de Hegel e Danto, tampouco de tratar apenas da morte da sua arte ou da exposição censurada.

Segundo Arthur Danto (2015), a teoria sobre o "fim da arte" de Hegel é relativa à distinção que ocorreu no significado da arte no período moderno em relação aos períodos anteriores. $\mathrm{O}$ fim da arte seria a descontinuidade histórica, pensando numa linearidade que a sucessão de períodos sugere, que surgiu no período moderno quando a produção artística, através de um "progresso cognitivo", passou a refletir sobre si mesma. Danto (2015, p. 144) escreve que para Hegel "a arte termina com o advento de sua própria filosofia" Segue que, no pensamento de Arthur Danto (2015, p. 145), após 1906, "a história da arte simplesmente parecia ser a história das descontinuidades", cada novo movimento se debruçava sobre suas próprias singularidades, o que afastava a arte de uma filosofia cultural aos moldes de Hegel, e começavam a aparecer as necessidades de compreensão teóricas sobre cada novo movimento. "Fim da arte" não deve ser entendido como o fim da produção artística, mas como o fim de uma determinada ideia de arte que deixou de ter uma continuidade linear dentro da história da arte. Posto isso, vale considerar que no entre promovido pela ironia de Bruscky parece haver outras possibilidades interpretativas e não apenas essa que estaria relacionada ao fim de uma forma de arte e o início de outra.

\footnotetext{
${ }^{9}$ Algumas pessoas reconheceram, em 2014, uma edificação na Rua da Aurora como sendo o local em que funcionaram o Doi-Codi e o DOPS. Ex-presos reconhecem locais em que funcionaram o Doi-Codi e o DOPS, no Recife. Comissão Nacional da Verdade. 15 out. 2014. Disponível em: http://www.cnv.gov.br/outros-destaques/558-ex-presosreconhecem-locais-em-que-funcionaram-o-doi-codi-e-o-dops-no-recife.html. Acesso em mai. 2017.
} 
O texto do convite santinho segue: "A família enlutada aproveita a oportunidade para avisar as pessoas de bom coração que a missa de ação de graças será realizada na Capela da Universidade Católica de Pernambuco no dia 21/10/1971. Às 7 horas". Uma nova série de incongruências abrem brechas para inferir ironia. Com a ideia de "família enlutada" supõe-se que há uma família que sofre e provavelmente sinta tristeza. No entanto, a família em questão, enlutada, aproveita a "oportunidade" (o santinho convite para o enterro) para convidar as "pessoas de bom coração" para uma "missa de Ação de Graças". As missas encomendadas por ocasião de falecimento são chamadas de missas de réquiem, ou missa de defunto. Há também a missa de corpo presente e aquelas por ocasião do tempo de morte: três, cinco, sete dias, um mês, um ano. Mas missas de Ação de Graças, ao contrário das missas de réquiem, são encomendadas e realizadas em comemoração à alguma graça alcançada e, supõe-se, quando graças são alcançadas o sentimento é próximo de ou é felicidade.

Uma missa de réquiem seria mais apropriada para um santinho convite. Mas talvez a circunstância fosse mais proveitosa para usar uma dose mais de ironia. Se acabaram com sua exposição, muito por conta de um moralismo cristão, como disse Sr. Brandley, basta agora que realizem uma missa de Ação de Graças. E, novamente, a ironia de Bruscky solapa o moralismo. O convite com data, hora e local para a celebração, embora não tenha sido encontrado registros sobre se a missa foi ou não realizada, colabora para que, entre um código e outro apareça o estranhamento e nele o fortalecimento da presença da ironia brusckyana, que leva a ideia da realização da missa de Ação de Graças até o espaço institucional da Universidade Católica de Recife, local que, segundo a matéria do jornal comentada anteriormente, Bruscky havia sofrido censura por parte de seus colegas:

$\mathrm{Na}$ Universidade Católica, onde estuda jornalismo, há dias, alguns de seus colegas retiraram um cartaz que estava afixado no recinto do estabelecimento, e também censuraram profundamente o artista, por estar empregando métodos que atentavam a moral cristã, inclusive, utilizando a figura de santos, com dizeres, onde convidava todos para a missa de sétimo dia, que era a inauguração da mostra de seus desenhos (...) (Empetur, 1971, p. 27)

A presença do jogo verbal deixa que Bruscky ironize não apenas o acontecimento na galeria da Empetur, mas os códigos da instituição arte, seus formatos de exposição, a sucessão de períodos - o início de um período sucede a morte de outro - e não desperdiça a oportunidade para jogar com códigos morais e religiosos e provocar, inclusive, seus colegas na Universidade.

Para Cristina Freire (2006, p. 93), em Arte Cemiterial (1971) Bruscky mistura as dimensões e funções "informativa, simbólica e lúdica" da arte, "a ideia do enterro remete simbolicamente ao luto em que vivia a população brasileira com a restrição de seus direitos civis numa sociedade ditatorial", e os convites, em formato de santinhos, seriam provocações ao moralismo vigente. Para Cristiana Tejo $(2009$, p. 32) "o ato é uma clara alusão a um sentimento generalizado de luto vivido pela sociedade brasileira". Adolfo Montejo Navas (BRUSCKY; NAVAS, 2012, p 52-53) comenta, em linhas gerais, que esse trabalho é uma amostra de que Paulo Bruscky se apropria do "labirinto urbano da cidade" para colocar em prática sua atitude irreverente com característica crítica". Afirmando que Bruscky vale-se da ambivalência, Ana Lúcia Marsillac (2011, p. 1297) acredita que a obra faz referência à morte da arte e que expor um caixão circulando pelas ruas em um contexto impregnado pelas mortes silenciosas e veladas, foi um gesto de ousadia e de denúncia social.

Certamente, Arte Cemiterial traz elementos para pensar a situação política e social do Brasil daquele momento. A restrição dos direitos, a perseguição, a tortura e a morte presente na sociedade durante a ditadura são evocadas por Bruscky ali, no calor do momento, como uma guerrilha, através da ironia. A ironia inferida no trabalho do artista não é aquela que pode apenas nos conduzir ao riso, mas sim a que pode provocar estranhamento e com ele a possibilidade de reflexão, portanto, ela é pensada como um ato social, como uma tática do artista para que seu posicionamento sobre as circunstâncias do período circulasse, ou seja, é vista como um jogo sério em que há relações ativas e variadas, é 
entendida como "uma estratégia discursiva que opera no nível da linguagem (verbal) ou da forma (visual, musical, textual)", e não apenas um tropo retórico limitado ou uma atitude diante da vida (HUTCHEON, 2000, p.20).

Se for considerado desde o convite no jornal para a abertura da exposição, o happening de chegada do artista à galeria da Empetur (ambos no dia 08/10/1971), os subsequentes comentários no jornal e o santinho com a proposta de enterro (com data para 16 de outubro de 1971) como uma grande proposta artística, ou mesmo como o desdobramento da ideia artística, haveria de ser pensado que, por causar ruído na cidade e no cotidiano cultural, social e político, seria mais pertinente tratá-la como uma intervenção urbana do que como uma exposição ou mesmo um happening.

Diante do contexto político e artístico do período, as agruras da ditadura militar e as alternativas vinculadas à arte conceitual, o todo poderia ser tratado como uma grande jogada irônica do artista que, por meio de múltiplos artifícios, provocou vãos entre os sentidos mais presentes - a morte como temática e subterfúgio para ações e proposições de arte conceitual - pois quando veicula seu gesto ousado, provocativo, de crítica e denúncia política e social ativa outros significados.

A ironia não é apenas ambiguidade. Há outros elementos que caracterizam a ironia além da ideia de que ela é uma coisa querendo dizer outra. Há o que Linda Hutcheon (2000, p. 63) chama de "arestas" da ironia: "a ironia tem arestas", "a ironia consegue deixar as pessoas irritadas", "a ironia decididamente tem os nervos à flor da pele", sua identidade transideológica e a característica de assumir formas variadas levanta tanto questões de risco como de recompensa. Ainda segundo Hutcheon (2000, p. 59), a ironia tem uma longa história como arma dos fracos, ou seja, da "cultura de resistência" contra uma cultura opressora. Nesse sentido, se a abertura da exposição que ofereceu um coquetel com pratos de capim e batida "sangue de vampiro" para os convidados, além disso, se a presença do caixão foi um risco diante da opressão da ditadura militar, se irritou os presentes e o diretor da galeria, pois se configurou como um atentado contra a moral cristã e o comportamento da sociedade, a recompensa foi a possibilidade de um desdobramento irônico da ação, em que mais uma vez o artista pode expor seu posicionamento crítico e resistente.

Uma das características da ironia é sua assimetria, seu desequilíbrio em favor daquilo que está no silêncio ou que não é dito. $O$ favorecimento daquilo que está oculto acontece, em certa medida, por meio do que é inferido "sobre a atitude do ironista ou do interpretador: a ironia envolve a atribuição de uma atitude avaliadora, até mesmo julgadora" (HUTCHEON, 2000, p. 63). A atitude avaliadora faz parte do quadro de intencionalidades da ironia, quer se acredite que ela sinalize uma crítica em forma de chiste, quer ela aponte distanciamento e desvalorização. Esteja ela indicando o desejo de diversão ou o compartilhar de um segredo (HUTCHEON, 2000, p. 65 - 72).

Interpretar a intervenção, num todo, como fazendo referência à situação política do Brasil é possível, como afirmam Cristina Freire, Cristiana Tejo e Ana Lúcia Marsillac. A simbologia do caixão remete à morte e, consequentemente, à situação de luto da sociedade brasileira diante da restrição dos direitos, das perseguições, das censuras, das torturas e das mortes impostas pela ditadura. Assim, a intervenção irônica de Bruscky pode ser pensada como enfrentamento e como um convite para que a sociedade repensasse a situação política e social do país.

Assim, se Bruscky jogava com as palavras, o "enterro da exposição" também pode ser entendido no sentido de que enterrar uma exposição é ocultar o que deveria ser visto. Embora a ironia não aconteça somente e necessariamente por inversão semântica, nessa interpretação talvez a inversão semântica seja importante, pois um antônimo de exposição é ocultação e o ato de enterrar é um modo de ocultar. Interpretado dessa maneira, entre a palavra enterro e a ação de enterrar na rua da Aurora, parece haver algo que dizia que se a "exposição" - que tocava também na situação política e social do país - seria enterrada ou ocultada, isso aconteceria abertamente, e diante de uma das sedes da repressão no Recife.

De modo geral, a ação do artista se configura como um desvio à norma, se não pelas propostas - "arte cemiterial” ou o desdobramento em "enterro da exposição" - pelo ruído provocado por meio da ironia 
e do cortejo pelas ruas da capital pernambucana. Ação, que provocou movimento nas ruas da cidade, desobedeceu a fronteira da ordem estabelecida, fabricando aquilo que Michel de Certeau (1998, p.203) chamou de espaço. O espaço vivido pela proposta artística atentava, então, contra a lei do lugar que seria a lei da ordem da cidade e da política daquele momento.

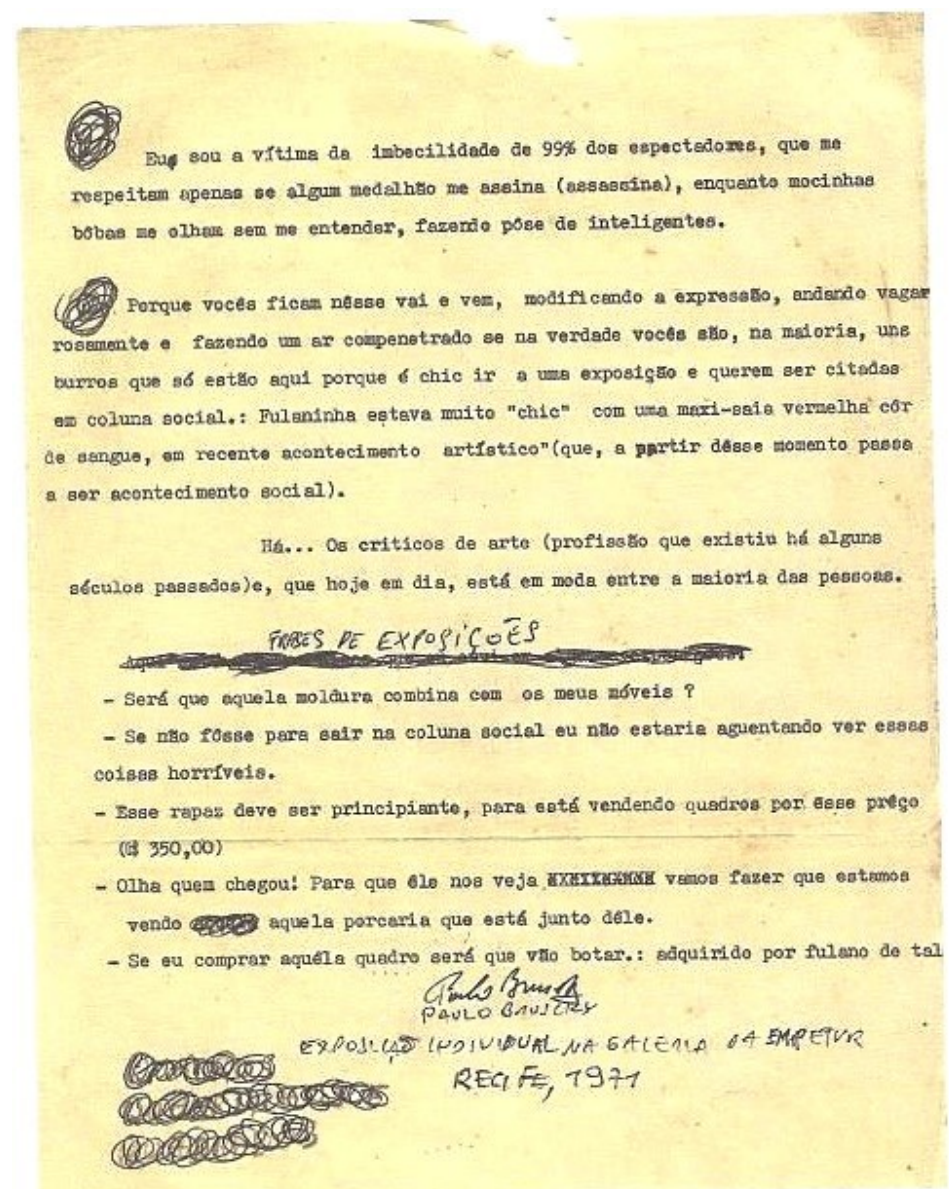

Figura 4 - Opinião da obra sobre o espectador. Paulo Bruscky, 1971.

\section{Opiniões da Obra}

Opinião da Obra sobre o espectador (Figura 4), é um texto que compôs a exposição Arte Cemiterial, em 1971. Escrito à máquina, em papel simples, com rasuras e borrões feitos à caneta, é estruturado de modo que provoca a leve sensação de que é possível ouvir os pensamentos de uma obra de arte. É um jogo de palavras que abre espaço para reflexões sobre a relação entre artista, obra, funções da arte, sistema da arte e público. No trabalho, como uma recriação recreativa, Bruscky parodia os possíveis comentários que espectadores e críticos de arte eventualmente tecem ou podem tecer em eventos artísticos. Em estreita relação com a ironia, a paródia, escreve Hutcheon (1985, p.17), é uma "forma de imitação caracterizada por uma inversão irônica, nem sempre à custa do elemento parodiado". Nesse aspecto, o trabalho seria uma paródia por possuir "repetições" de palavras ou pensamentos, mantendo uma "distância crítica", pois as palavras não são ditas nem pela obra, nem pelo público, e "marcam a diferença em vez da semelhança" (HUTCHEON, 1985, p. 17) justamente por conterem arestas irônicas.

Há uma incidência de elementos recorrentes na poética de Bruscky, explicitados por meio da relação entre os aspectos visuais e os verbais, a estreiteza na relação da obra com o observador, metalinguagem e ironia. Tais relações estão de acordo com a ideia de paródia tal como é apresentada por Linda Hutcheon (1985, p. 17), que seria uma forma de discurso que utiliza a imitação, não necessariamente ridicularizadora, apesar de poder ter uma intenção irônica ou chistosa, tem como 
alvo, de modo geral, outra forma de discurso codificado ou uma obra de arte, está presente em todas as esferas artísticas do século XX, incorporada como comentários críticos dentro de suas próprias estruturas, funcionando reativamente à desconfiança da crítica exterior. A paródia, muitas vezes, é um metadiscurso: um "comentário crítico" autolegitimador, autorreferencial e autorreflexivo.

A ideia do texto como obra e a apresentação da obra como "opinião" leva a pensar o texto como transcrições da oralidade para o sistema escrito. No primeiro momento como uma "voz" do pensamento, mas de um objeto inanimado, a própria obra de arte expressa sua indignação e expõe sua opinião através do texto. Nesse sentido, a obra deixaria a suposta passividade que leva a crer que ela pode apenas receber críticas, para ativamente criticar, como se tivesse vida e liberdade para ponderar, ela mesma, sobre sua estada no mundo. No segundo momento, ainda como uma "voz" da obra, a mensagem é mais de reflexão, repetição e pouco caso. A "voz" repete, faz paródia das expressões mais banais que ela supostamente ouviu de espectadores em exposições de arte. É o eco de outras vozes, espectadores e críticos de arte, o que "ouvimos" da obra, ou melhor, lemos da voz transcrita por Bruscky no texto/obra. A estrutura transcritiva trabalhada pelo artista na obra/texto, pensando bem, também é repetida nesse estudo.

Nas artes visuais, segundo Linda Hutcheon $(1985,27)$, a paródia pode se manifestar através da repetição de obras específicas ou utilizando os códigos convencionados. As convenções podem ser em relação às questões formais da arte, em relação à experiência estética do público e até mesmo pertinente aos códigos comportamentais - tanto do público quanto da crítica e do sistema da arte. Tais manifestações funcionariam como espécies de "reciclagens artísticas", pois teriam como alvo obras de arte, partes de obras, características estéticas, estilos de um período ou todo um movimento artístico. Essa variedade de alvos é decorrente das intencionalidades complexas que tanto a paródia como a ironia carregam. Apesar disso, a intencionalidade na paródia não precisa estar excessivamente ou necessariamente escondida, ainda que possa ser complexa.

Jogando com o que Hutcheon (1985, p.15), chama de "tensões criadas pela consciência histórica", Bruscky parece olhar não só para o passado, mas para o presente, para o modo como aconteciam os salões e as premiações de arte, para repensar a ideia de exposição, valor do objeto artístico, o que seriam obras e quais as funções do observador e, a partir daí, reestrutura o apreendido, transferindo valores e reorganizando elementos. Pensando a estrutura visual do trabalho, fica evidente o descaso com o aspecto estético. O desdém, apresentado intencionalmente, é trazido em forma de erros e borrões que denotam a despreocupação com a apresentação final que um trabalho de arte poderia requerer.

O primeiro parágrafo da "opinião" da obra diz: "Eu sou vítima da imbecilidade de 99\% dos espectadores, que me respeitam apenas se algum medalhão me assina (assassina), enquanto mocinhas bobas me olham sem me entender, fazendo pôse [sic] de inteligentes". De alguma forma, é o pensamento do artista que é exposto através do que ele chama de "opinião da obra". Há, logo na primeira frase, dois elementos que denunciam algum sentimento de indignação do artista em relação aos espectadores: a obra (no caso a sua produção artística) é vítima, ou seja, sofre de algum mal que é oriundo da estupidez de quase $100 \%$ dos espectadores, o que é confirmado ao final da frase quando diz: "mocinhas bobas me olham sem me entender". O mal, que faz da obra uma vítima, também é esclarecido já na sequência, parte da frase em que se lê que a obra só é "respeitada", ou seja, reconhecida como obra, se receber do sistema artístico um aval que a legitime, fato que, pela dependência desse sistema, colabora com sua morte ou a providencia. A legitimação é, na passagem, literalmente um assassinato, já que o que predomina não é o conhecimento em relação à produção de arte, mas as "poses" de um público que se diz entendido.

A ocorrência da paródia, ainda que por meio da repetição, ou seja, da incorporação de elementos já existentes, que nesse caso seriam o sistema artístico e o público, teria a função de separação e contraste, e por isso exigiria uma distância crítica e irônica também do interpretador. A paródia, que 
é dependente da atribuição de significado, ou seja, necessita que o decodificador da mensagem acesse uma espécie de código para compreender as alusões ou as citações contidas nela, seria neutralizada se a aresta crítica da ironia não fosse percebida. Não perceber a ironia em uma obra de paródia ocasionaria perda de parte significativa tanto da forma quanto do conteúdo, pois, explica Hutcheon (1985, p. 54), "tanto a codificação como o compartilhar de códigos entre produtor e receptor são centrais" para o "correto" funcionamento da paródia, além dos aspectos da "inversão irônica" que a caracteriza. Contudo, é preciso notar que a inversão irônica não se dá exclusivamente na forma do "riso ridicularizador", pois muitas vezes a ironia sequer provoca o riso.

O segundo parágrafo da "opinião" segue reafirmando a postura aguda do artista que, através da obra, declara seus pensamentos sobre a ignorância do público de arte, isso ocorre principalmente na passagem "(...) fazendo um ar compenetrado se na verdade vocês são, na maioria, uns burros (...)". Nesse trecho o artista esboça seu tom de provocador de contrariedades, pois quem esteve na exposição e observou o papel contendo o texto, num primeiro momento, poderia tê-lo visto como um objeto de arte, ainda que pensasse ser de mau gosto, exposto em uma galeria de arte ou, talvez, como um erro - do artista, de um possível curador, ou de quem tenha montado a exposição. O público, talvez, possa ter tido a impressão de que ficava sabendo do pensamento de alguém sobre outrem, como se estivesse a espreitar algo risível, mas o texto é dirigido para quem o leu. Nesse sentido, quem acompanhasse as frases da obra passaria, imediatamente, a fazer parte dela. Ironicamente, entraria no jogo completando não só a comunicação - emissor - mensagem - receptor, como também a própria obra. O observador, nesse caso, acabaria se percebendo como alvo da ironia ou do procedimento chistoso do artista, salvo se se considerasse parte do $1 \%$ do público de arte que o artista ou, para entrar na proposta de Bruscky, a obra não considerava imbecil.

O terceiro parágrafo é um ataque à crítica de arte: "Há.... Os críticos de arte (profissão que existiu há alguns séculos passados) e, que hoje em dia, está em moda entre a maioria das pessoas". Ao dizer que a profissão existiu no passado, afirma também que a crítica profissional, com uma função séria, não existia mais. Se existiam críticos, estes eram burros e imbecis ("imbecilidade de 99\%" e "vocês são, na maioria, uns burros") que seguiam um modismo. O Chiste, semelhante à ironia, segundo Freud (1959, p. 216), "apresenta ao ouvinte dupla fisionomia e obriga-o a duas diversas interpretações", pois, através da fusão de dois ou mais elementos produz novos sentidos.

Em Opinião da Obra sobre o espectador, Bruscky funde a opinião da obra com o que ela pode ouvir dos espectadores, funcionando tanto como um ataque irônico do artista à "imbecilidade de $99 \%$ dos espectadores" e à crítica de arte, como mostra, nas frases seguintes, a confirmação da burrice daqueles que frequentavam às exposições de arte mais para serem vistos do que para verem e que, incultos e desrespeitosos, teciam comentários sobre questões ligadas ao status social mais do que ligadas ao evento artístico, ao artista, às obras de fato ou à situação real da sociedade.

A ironia é uma forma de expressão sofisticada que afasta o decodificador ou o interpretador do sentido superficial, o que o faz inferir outro sentido, e a paródia, também sofisticada, exige que o decodificador construa um novo sentido agregando informações na obra parodiada (HUTCHEON, 1985, p.15). Complementares, ironia e paródia, uma provoca a outra e por isso é difícil afastar as táticas pragmáticas de uma e outra. De tal modo, nesse trabalho, o artista parece jogar tanto com a linguagem literal quanto com a artística e põe em jogo não apenas o que está explícito, aquilo que o texto nos mostra ou o que nos diz o título do trabalho. Há elementos implícitos, é uma construção metalinguística, ou melhor, que se dá através da paródia irônica, porquanto, através dela a arte olha para a sua própria condição e comenta sobre isso. Além disso, ácida, a ironia coloca também uma aresta no espectador, pois quando leu o texto ele pôde perceber que se tratava de algo sobre si mesmo. $\mathrm{O}$ espectador era o alvo da crítica no exato momento em que completava a crítica ao lê-la. Bruscky ao apresentar Opinião da Obra sobre o espectador, em 1971, na exposição Arte Cemiterial, provocava o público, tirava os espectadores de uma passividade inserindo-os na exposição. Mas 
talvez essa opinião dada em forma de obra possa ter provocado a ira dos visitantes e então colaborado para que a exposição tivesse a repercussão pública negativa que teve.

Além da intenção do autor, que são expressas de forma codificada, estão implicadas as questões em torno da decodificação e os elementos contextuais, ou seja, para a paródia atingir seu efeito é necessário que o receptor da obra tenha acesso aos elementos contextuais e possa decodificar a mensagem. Alguns elementos contextuais estão presentes nas "Frases de Exposições" no texto. Deflagradoras de ironias, da primeira até a última frase o que se tem é uma explanação de pensamentos da obra (do artista) relacionados à individualidade e à ignorância do espectador de arte. A preocupação se a moldura da obra combinará com os móveis é irônica em relação à ignorância e ao pensamento consumista; a preocupação com a coluna social é ironia em relação ao comportamento de uma classe que se preocupava e se ocupava em manter um status social mesmo diante do contexto político, ambas são críticas à incoerência das pessoas que se comportavam como se soubessem tudo sobre arte, mas que sequer entendiam da produção de Bruscky daquele momento, que era coerente com o que acontecia na arte experimental, de matriz conceitual, no Brasil.

Outra questão levantada por Opinião da Obra sobre o espectador é a do valor de uma obra versus a valorização decorrente da experiência do artista, como pode ser visto na frase "Esse rapaz deve ser principiante (...)". A preocupação com o valor de um objeto de arte é pouco coerente com a produção de arte conceitual, pois o acento da arte conceitual não estava no objeto, mas na ideia artística. Seguindo tal raciocínio, a análise aponta novamente para uma não compreensão do público e de grande parte da crítica recifense sobre a produção de arte daquele momento. A frase da obra que reafirma essa incompreensão seria: "vamos fazer que estamos vendo aquela porcaria", a passagem denota novamente, a preocupação com o status, confirmada, igualmente, pela frase seguinte que é também a última: "Se eu comprar aquele quadro será que vão botar: adquirido por fulano de tal".

Analisando a ideia de sobreposição de sentidos explicada por Hutcheon na construção da paródia, um superficial e explícito e outro profundo e implícito, Opinião da Obra sobre o espectador gera, em síntese, novas possibilidades de significados. Essas possibilidades de ressignificação surgem da repetição com diferença entre textos (ou informações), portanto, esse trabalho se afasta de normas estéticas ao mesmo tempo em que as inclui como material de fundo e expõe seus mecanismos de ação através da utilização e coexistência de códigos diferentes nas próprias mensagens.

Evidenciando a ironia, a metalinguagem e a paródia, os comentários ácidos feitos através da "Opinião da obra", são dirigidos ao sistema da arte e ao público frequentador das exposições, das galerias e dos museus, que fazia parte da elite social. Apesar da postura crítica e ácida de Bruscky, ela não significa uma repulsa à arte, todavia é também a expressão de um sentimento de defesa de sua prática artística e, parece, uma tentativa de provocar alguma mudança nas posturas e nos modos de ver de seus espectadores.

Lembrando que uma das principais estratégias da paródia é a ironia, e que a ironia, por ser uma figura de linguagem, pode possuir inúmeros significados, inclusive ambíguos, juntas, ironia e paródia, tornam-se maneiras importantes para criar níveis de sentido. A ironia serve ao decodificador para interpretar e avaliar a mensagem, ainda que haja certa literalidade, que nesse trabalho está presente na explicação que o título faz sobre a própria obra. Entretanto, há um texto (informação) de fundo contra o qual será apresentado outro texto (informação irônica inferida) que deve ser compreendido, e é entre as informações dadas pelo texto que o artista joga a sua arte e com a sua arte para e contra o seu público. A ironia, que tanto pode ser encontrada entre o que é afirmado quanto no que é significado, tem também outro papel, o de julgar: "Ambas as funções - inversão semântica e avaliação pragmática - estão implícitas na raiz grega, eironeia, que sugere dissimulação e interrogação: há uma divisão ou contraste de sentidos, e também um questionar ou julgar" (HUTCHEON, 1985, p. 15). 


\section{Considerações finais}

No Brasil, já nos primeiros anos do conturbado período da ditadura militar - segunda metade da década de 1960 - cresceram as discussões em torno dos limites da arte e as propostas artísticas com viés conceitual ganharam força. Contudo, no caso brasileiro, e no dos países latino-americanos que viveram sob ditaduras entre as décadas de 1960 e 1970, essas discussões em torno da arte avançaram para o contexto social e político e, prosseguindo pela década de 1970, acenderam como formas de crítica, resposta, resistência e denúncia às ditaduras e às questões sociais da época. Tal produção ocupou meios e espaços expandidos, tanto em manifestações individuais como coletivas e, muitas vezes, inseriu o espectador como parte de proposições. Algumas dessas propostas carregaram a ironia como recurso poético e como tática discursiva para veicular, entre ditos e não ditos, conteúdos críticos que poderiam ser, e várias vezes foram considerados subversivos e censurados.

De tal modo, entre truques, metáforas e, por vezes, com um humor ácido, a volumosa e variada produção de Paulo Bruscky tem, como traço recorrente, a presença da ironia. Elemento que pode, ao nível semântico, marcar diferenças de sentido - o que é afirmado/o que é intencionado - como pode, ao nível pragmático, avaliar. No caso da proposição Arte Cemiterial e em Opinião da obra sobre o espectador a ironia de Bruscky, avaliando e julgando, parece mais evidentemente direcionada ao sistema artístico e ao público de arte. Isso porque, em certa medida, algumas vezes, o artista deixou transparecer seu posicionamento em relação ao sistema de arte brasileiro de modo mais direto, como pode ser percebido na matéria veiculada no Jornal do Brasil em setembro de 1972, quase um ano depois da Arte Cemiterial. Nessa ocasião, o artista dizia que o prato de capim, servido na mesma exposição em que Opinião da obra sobre o espectador, era uma vingança contra os marchands que eram "agiotas da arte":

(...) quando lancei a arte cemiterial aqui no Recife, em agosto de 1970. Só alguns jornais tomaram conhecimento. Em outubro de 1971 resolvi transformar minha idéia numa exposição. Cheguei ao local dentro da obra principal: um caixão mortuário, transportado de uma casa funerária até a empresa Pernambucana de Turismo, onde me esperavam os convidados". Duas semanas depois, segundo ele, o pintor pernambucano José Tarcísio, residente no Rio, fez uma exposição idêntica. "e talvez com menor agressividade - acrescentou Paulo - pois ele apenas expôs o caixão, não foi como eu um objeto no interior da esquife. Mas ele viajou para a França, foi filmado e teve inclusive propostas de compra da obra por um museu notadamente quadrado. Quanto a mim, fui expulso. Ninguém aceitou nada. (...) É isso que acontece em geral com o pintor pernambucano que não abandona Recife. Falta de ajuda, necessidade de concessões para obter pequenas oportunidades, desinteresse em promover nosso trabalho. (OLIVEIRA, 1972, p. 5).

A matéria, apesar de conter algumas informações conflituosas em relação à algumas fontes sobre a exposição ${ }^{10}$, traz a declaração do artista que colabora para refletir sobre o posicionamento dele em relação à arte, que pode ser entendido como uma forma de lamento - sobre o não entendimento e a não aceitação de sua arte - ou, mais coerente com o comportamento de Bruscky - que inclusive buscava formas alternativas de produção e circulação de seus trabalhos - como uma forma de enfrentar o sistema artístico tido como hegemônico. Lendo o discurso de Bruscky, que defendia sua ideia como original, mas que foi pouco valorizada porque ele permaneceu no Recife, o que seria uma região periférica, considerando que o centro estaria, principalmente, entre Rio de Janeiro e São Paulo, uma reflexão possível seria supervalorizar a preocupação do artista com a sua inclusão e aceitação no

\footnotetext{
${ }^{10} \mathrm{Na}$ matéria veiculada no Jornal do Brasil, Bruscky afirma ter chegado na galeria dentro da urna mortuária, no entanto, as imagens documentais da ação do artista no happening de chegada na galeria de arte da Empetur indicam que Bruscky teria chegado dentro do carro funerário e entrou na exposição carregando, com ajuda, o caixão e não dentro dele.
}

R. Inter. Interdisc. Art\&Sensorium, Curitiba, v.7, n.1, p. 215 - 233 Jan.- Jun. 2020 
sistema de arte, algo que, de certo modo, esvaziaria a potência crítica, política e social não só da exposição Arte Cemiterial e seus desdobramentos como de toda a produção desse artista.

Questionando o sistema da arte e o comportamento do público através do próprio sistema; propondo o repensar sobre esse sistema, a arte e suas funções, Bruscky, nos trabalhos aqui vistos (e em vários outros), subvertia não apenas os códigos artísticos mais tradicionais, principalmente porque sua produção não tem a crítica centrada na instituição arte ou no objeto artístico. Todavia, Bruscky subvertia, especialmente, a ordem política da ditadura - que censurava, reprimia, perseguia, ameaçava, prendia, matava - e os códigos sociais, morais e religiosos presentes na sociedade daquele momento. Uma das formas de Paulo Bruscky mostrar seu posicionamento crítico, como aqui se pensa, foi através do jogo sério da ironia que, como tática subversiva, muitas vezes trabalha para mudar a maneira de interpretar das pessoas.

\section{Referências:}

BRUSCKY, P.; NAVAS, A. Poiesis Bruscky. São Paulo: Cosac Naify, 2012.

CERTEAU, M. de. A Invenção do cotidiano. $3^{\mathrm{a}}$ ed. Rio de Janeiro: Vozes, 1998.

COHEN, R. Performance como linguagem: criação de um tempo-espaço de experimentação. São Paulo: Perspectiva, 2002.

DANTO, A. O fim da arte. In: DANTO, A. O descredenciamento filosófico da arte. Tradução de Rodrigo Duarte. Belo Horizonte: Autêntica, 2015. p. 117-152.

FREIRE, C. Arte Conceitual. Rio de Janeiro: Zahar, 2006.

. Arte conceitual depois da arte conceitual. In FREIRE, C.; LONGONI, A. Conceitualismos do Sul/Sur. São Paulo: Annablume; USP-MAC; AECID, 2009. p.165 - 181.

. Paulo Bruscky: Arte, arquivo e utopia. São Paulo: Cepe, 2006.

. Poéticas do Processo: Arte Conceitual no Museu. São Paulo: Iluminuras, 1999

FREUD, S. O chiste e sua relação com o inconsciente (1905). In: FREUD, S. Obras completas de Sigmund Freud. Tradução de C. Magalhães de Freitas e Isaac Izecksohn. Rio de Janeiro: Delta. v.V, 1959. p. 3-242.

HUTCHEON, L. Teoria e política da ironia. Belo Horizonte: UFMG, 2000.

. Uma teoria da paródia: ensinamentos das formas de arte do século XX. Tradução Teresa Louro Pérez. Rio de Janeiro: Edições 70, 1985.

MARSILLAC, A. L. Paulo Bruscky e a liberdade de olhar. In: ENCONTRO DA ASSOCIAÇÃO NACIONAL DE PESQUISADORES EM ARTES PLÁSTICAS, 20, 2011. UERJ. Anais do $20^{\circ}$ Encontro Nacional de Pesquisadores em Artes Plásticas: Subjetividades, utopias e fabulações. Rio de Janeiro: ANPAP, 2011, p.p. 1293 - 1307.

MATOS, L. Arte é este comunicado agora - Paulo Bruscky e a Crítica Institucional. Concinnitas Revista do Instituto de Artes da UERJ, Ano 8, v. 10, p. 119-132, jul. de 2007.

MENEZES, R. A imagem sagrada na era da reprodutibilidade técnica: sobre santinhos. Horizontes antropológicos. Porto Alegre, no. 36, v. 17, p. 43-65, dez. 2011.

TEJO, C. Paulo Bruscky: Arte em todos os sentidos. Recife: Zoludesign, 2009.

\section{Fontes:}

ALBERTO, J. Exposição de Paulo Bruscky. Diário de Pernambuco, Recife, 8 out. 1971, p. 3. 
BRUSCKY, P. Entrevista para Augusto César Costa. Em Programa Nomes do Nordeste. Fortaleza, 15 mai. 2007. (53'66"). Disponível em: https://youtu.be/WeKZ7pIUqC4. Acesso em 30 jun. 2017.

CÂMARA FILHO, J. Lutando nos Salões. Diário de Pernambuco Recife, 2 fev. 1969. Terceiro Caderno, Coluna Arte e Outras, p. 4.

Cemitério é tema de pintura. Diário de Pernambuco. Recife, 6 ago. 1970, p. 1.

COUTINHO, V. Flagrantes. Diário de Pernambuco, Recife, 7 out. 1971, p.6.

COUTINHO, V. Flagrantes. Diário de Pernambuco. Recife, 18 jul. 1970, $2^{\circ}$ Caderno, p. 5.

Empetur retira caixão de defunto de mostra de arte. Diário de Pernambuco, Recife, 10 out. 1971, Primeiro Caderno, p. 27.

Exposição falava de morte mas todos estavam pensando na vida. Diário de Pernambuco, Recife, 17 out. 1971, p. 15.

Ex-presos reconhecem locais em que funcionaram o Doi-Codi e o DOPS, no Recife. Comissão Nacional da Verdade. 15 out. 2014. Disponível em: http://www.cnv.gov.br/outros-destaques/558-expresos-reconhecem-locais-em-que-funcionaram-o-doi-codi-e-o-dops-no-recife.html. Acesso em mai. 2017.

OLIVEIRA, A de. Livro 7, Sede da Vanguarda. Jornal do Brasil. Rio de Janeiro, 21 set. 1972, p.5

Paulo Bruscky. Diário de Pernambuco. Recife, 7 ago. 1970, p. 11.

Pintores promovem o sepultamento da arte em B. Viagem. Diário de Pernambuco. Recife, 31 out. 1970, p. 3.

Recifense verá arte cemiterial. Diário de Pernambuco. Recife, 6 ago. 1970, p. 3. 